\title{
Modeling Spatial Distribution of 3D Isotropic Hydraulic Conductivity Based on HC-System for Fractured Groundwater Flow Media using Neural Network Case Study Grasberg Open Pit of PTFI
}

\author{
Tedy Agung CAHYADI ${ }^{1, \mathrm{a}}$, Lilik Eko WIDODO ${ }^{2}$, Irwan ISKANDAR ${ }^{2}, \mathrm{SUKAERANG}^{3}, \mathrm{SUYONO}^{4}$ \\ ${ }^{1}$ Post Graduate Student, Mining Engineering, ITB \\ ${ }^{2}$ Lecturer, Mining Engineering, ITB \\ ${ }^{3}$ Geoservice Grasberg Hydrogeology PT Freeport Indonesia \\ ${ }^{4}$ Lecturer, Mining Engineering, UPN "Veteran” Yogyakarta \\ ${ }^{a}$ Corresponding author: tedyagungc.students.itb@gmail.com
}

\begin{abstract}
Hydraulic conductivity property is very important for groundwater flow modeling. It can be gathered through packer test and slug test. The high cost of the operational implementation of these tests lead to the limited availability of observational-based distribution of hydraulic conductivity data. Highly fractured rocks in Grasberg open pit mining and surrounding of PT Freeport Indonesia (PTFI) result in fractured-groundwater-flow media. It is related to the complex geological structure and lithological condition. Groundwater modeling needs $3 D$ distribution data such hydraulic conductivity $(K)$. On previous research, hydraulic conductivity is distributed homogenyneously at each layer model. In this paper, under limited observational hydraulic conductivity, isotropic hydraulic conductivity will be modeled based on the HC-System approach and will be three-dimensionally distributed using Artificial Neural Network (ANN). HC-System approach will be developed according to the packer test and slug test measurement using geotechnical data from drilling such as Rock Quality Designation (RQD), Lithology Permeability Index (LPI), Depth Index (DI), and Gouge Content Index. HC-System approach will be resulted in isotropic distribution of hydraulic conductivity. It is then checked at some points by the packer tests and slug tests observational data. It is further very beneficial for modeling of groundwater distribution flow with the heterogeny hydraulic conductivity.
\end{abstract}

Keywords: hydraulic conductivity, modeling tree dimensional (3D) distribution, neural network (NN), HC-System

\section{INTRODUCTION}

Highly fractured rocks in Grasberg open pit mining and surrounding of PT Freeport Indonesia (PTFI) result in fractured-groundwater-flow media. It is due to the complex geological structure and lithological condition. Groundwater modeling needs 3D distribution data such as hydraulic conductivity $(\mathrm{K})$. According to previous study from HCI (2003), hydraulic conductivity is modelled homogenously for every lithology. Available limited packer and slug test were conducted to determine observational hydraulic conductivity. Packer test results are available in 2 boreholes and 18 target points. Moreover, slug test are available in 31 boreholes. Limited number of slug test and packer test, may not be enough to be used to estimate the spatial distribution of hydraulic conductivity on rock mass at Grasberg and surrounding. Drainage system, such as dewatering drain holes are needed to be installed on appropriate targets and can be judged as successfull if hydraulic parameter for groundwater model input is adequate. In this case, under limited insitu data, 3D distribution of hydraulic conductivity is modeled by HC-System approach (Hsu et al, 2009) and has been distributed using Artificial Neural Network (ANN). HC-System approach was developed based on the 49 test points of packer test and slug test. It is then used to model isotropic hydraulic conductivity based on information of rock quality designation (RQD), lithology permeability index (LPI), depth index (DI) and gouge content index (GCI) observed at 500 geotehcnical drill holes leading to the modeled hydraulic conductivity at the corresponding points. These modeled isotropic hydrulic conductivity data were then used to train ANN and finally results in more than 4896 points of additional isotropic hydraulic conductivity.

\section{GEOLOGY}

The Grasberg open pit mine is located within the Papuan fold belt on the northern margin of the Indo-Australian plate. Late Miocene arc collision resulted in regional northeast-southwest compression and formation of thrust and fold structures in the Papuan fold belt. There are two fundamentally different protoliths within the GIC: the Dalam Volcanic Breccia Group (DBG) and the Quartz Monzodiorite Group (QMG). The DBG includes the Dalam Andesite and the Dalam Fragmental units. The QMG includes the Early Kali, Late Kali, Main Grasberg Intrusive, and the Dalam Diorite units. The hydrothermal alteration types are roughly concentrically zoned within the diatreme, and alteration types commonly overlap and create several type materials, included: Poker Chip, Dalam Fine, and Hard Zone (Silaen et al, 2011).

\section{HIDROGEOLOGY}

According Silaen et al 2011, the occurrence of aquifers in and around the Grasberg Intrusive Complex (GIC) is related to secondary geological structures and a concentric permeability zonation across the boundary of the GIC. Based on existing geological information and current understanding from investigative drilling, the conceptual hydrogeological model of the Grasberg 
comprises:

1. The GIC (permeable locally where structures occur); comprising three intrusives (Dalam, Kali, and MGI - Main Grasberg Intrusive).

2. An inner contact zone (permeable) between the GIC and the Heavy Sulphide Zone (HSZ).

3. The HSZ (variable permeability).

4. An outer contact zone (permeable) between the HSZ and adjacent marble zone.

5. The marble zone (low permeability).

6. Limestone country rocks outside the GIC (permeable, where secondary structures occur)

\section{HC-SYSTEM}

HC-System approach Hsu et al (2009) in this study was developed according to the packer test and slug test measurement using geotechnical data from drilling, such as rock quality designation (RQD), lithology permeability index (LPI), depth index (DI), and gouge content designation (GCD). HC-System approach is resulted in distribution of hydraulic conductivity that is assumed as isotropic. HC-Index is an empirical method to estimate $\mathrm{HC}$-value ( $\mathrm{HC}$ ), and then the $\mathrm{HC}$ values which plotted in scatter plot against hydraulic conductivity from packer and slug test at same zone. The $\mathrm{HC}$ value equation from that parameter is shown in equation (1) below.

$H C=\left(1-\frac{R Q D}{100}\right) \cdot(D I) \cdot(1-G C D) \cdot(L P I)$

Where:

HC : HC Value

RQD : rock quality designation

DI : depth index

GCD : gouge content designation

LPI : lithology permeability index

RQD value is an indicator of rock mass condition in term of fragmentation within it. From hydrogeological point of view, fractured rock mass ore later on known as fractured media has more ability to transmit water from and into the formation than ordinary porous media. Following Deere et al (1967), the RQD value is defined as the cumulative length of core pieces longer than 100 $\mathrm{mm}$ in a run $\left(R_{S}\right)$ divided by the total length of the core run $\left(R_{T}\right)$ and can be expressed in the equation (2).

$R Q D=\frac{\sum R_{S}}{R_{T}} \times 100 \%$

Position in subsurface will affect the permeability. The decrease in permeability with depth in fractured rocks is usually attributed to reduction in fracture aperture and fracture spacing. The reduction is due to the effect of geostatic stresses, and thereby the permeability of fractured rocks will be reduced. The depth may be considered as a factor in evaluating rock mass permeability (Lee et al, 1993). To assess the influence of the depth on permeability, a depth index, namely $D I$, was defined according Hsu et al (2009) as follows.

$D I=1-\frac{L_{C}}{L_{T}}$

in which $L_{T}$ is the total length of a borehole; $L_{c}$ is a depth which is located at the middle of a double packer test interval in the borehole. In this study, the author combined packer test and slug test. In slug test case, $L c$ is a depth which is located at the middle of screen in borehole. In Hsu et al (2009), length of borehole was only for vertical hole, but in this paper, since the boreholes are incline and decline holes, therefore in this study the length of incline hole $\left(L_{T}\right)$ was transformed to vertical length of borehole.

The $R Q D$ value may decrease by increasing number of fractures in a core run. If the fractures contain infillings such as gouges, the hydraulic conductivity of the rock decreases because the cracked rock was blocked by filling material. To assess the influence of the gouge materials on hydraulic conductivity, a gouge content designation $(G C D)$ index was defined as follows.

$G C D=\frac{R_{G}}{R_{T}-R_{S}}$

in which $R_{G}$ is the total length of gouge content from the total of core run. The value of $G C D$ is always greater than zero and less than one. The greater GCD value stands for more gouge content in a core run, and thereby it will reduce the permeability. In this study, it has been assumed no GCD data from drill log. The value of GCD has been assumed to be proportional with RQD. Therefore, when RQD value is greater, 90\%-100\%, the permeability decreases. Accordingly, the GCD value is set to be within 0,9-1. It means that GCD does not present on core run.

Lithology is the intrinsic character of a rock in terms of mineral composition and grain size. For an intact rock, the magnitude of permeability depends largely on the individual character of the rock matrices. It may be affected by the average size of the pores, which in turn is related to the distribution of particle sizes and particle shape. To assess the influence of lithology on permeability, a lithology permeability index $(L P I)$ was defined as Table 1 according Hsu et al (2009). 
Table 1 Rating for LPI values based on lithology in the study area

\begin{tabular}{|c|c|c|c|}
\hline Lithology & Suggest Rating & Lithology & Suggest Rating \\
\hline Andesite & 0.15 & Sandy dolomite & 0.95 \\
\hline Trachyandesite & 0.15 & Silty dolomitey & 0.95 \\
\hline Hydrothermal breccia & 0.1 & Gravel & 1 \\
\hline Intrusive breccia & 0.1 & Limestone & 0.7 \\
\hline Diorite & 0.15 & Limestone breccia & 1 \\
\hline Porphyritic diorite & 0.15 & Dolomitic limestone & 0.7 \\
\hline Monzonite & 0.15 & Sandy limestone & 0.4 \\
\hline Porphyritic monzonite & 0.1 & Silty limestone & 0.3 \\
\hline Quartz diorite & 0.15 & Mudstone & 0.3 \\
\hline Quartz diorite porphyritic & 0.15 & Shale & 0.5 \\
\hline Quartz monzonite & 0.15 & Shale carbonaceous & 0.75 \\
\hline Quartz monzonite porphyritic & 0.15 & Shale limey & 0.6 \\
\hline Tuff & 1 & Sandstone & 1 \\
\hline Alluvium & 1 & Limestone sandstone & 0.95 \\
\hline Colluvium & 1 & Sandstone breccia & 1 \\
\hline Rehandle Material & 1 & Sandstone breccia & 1 \\
\hline Sedimentary breccia & 1 & Limey sandstone & 0.3 \\
\hline Tectonic breccia & 1 & Silty sandstone & 0.3 \\
\hline Conglomerate & 1 & Siltstone & 0.3 \\
\hline Clay & 0.3 & Dolomitic siltstone & 0.2 \\
\hline Dolomite & 0.7 & Limey siltstone & 0.3 \\
\hline Dolomite breccia & 0.85 & Sandy siltstone & 0.2 \\
\hline Limey dolomite & 0.7 & & \\
\hline
\end{tabular}

\section{ARTIFICIAL NEURAL NETWORK (ANN)}

The ANN is a computational system basic idea by the study of biological neural processing. One of the advantages of ANNs over conventional models is that it does not require determining a specific function to express the relationship between input and output variables, it can be also achieved by the train analysis (Schaap and Bouten, 1996). There are various sorts of ANNs, which are differ in their functions, such as prediction, classification, and filtering.

In this study, hydraulic conductivity from packer test, slug test and from HC-System approach were spatially distributed using ANN with architecture consists of $X$ (abcis), Y (ordinate), Z (elevation) as an input, $\mathrm{K}$ (hydraulic conductivity) as output and 2 hidden layers with different nodes. The customized ANN consists of 1 input layer with size 3 (x,y,z: location of data), 2 hidden layers with alternative 3,6,9 nodes from input layer and 1 nodes to output layer as well as 1 output layer (log K-training). In this study, the customized ANN is designed to get best performance of network training. The first hidden layer uses log-sigmoid (logsig) transfer function, which is $\operatorname{logsig}(\mathrm{n})=1 /(1+\exp (-\mathrm{n}))$. The second hidden layer uses purely linear transfer function, thus every result is summed linearly. Levenberg-Marquardt algorithm is used in training algorithm.
According to this ANN architecture, segmentation processes are perrformed. Data will be trained to get pattern distribution with log-sig function. Different layer, node and segment are trained to get best value of mean square error (MSE). Higher number of nodes and more segments tend to give bad performance as ANN has to train using more function and it needs more time to finish iteration. The ANN design is set with 20.000 epoch. Different size and number of grids may affect the performance of ANN and accordingly may affect the performance of hardware specification being used for modeling 3D hydraulic conductivity distribution.

\section{RESULT AND DISSCUSSION}

\section{Hydraulic Conductivity from Field Testing}

Based on the field testing result that is given in Table 2, it can be seen that hydraulic conductivity in the study area is heterogeneous. Lithology is dominantly controlled by structure and fracture. From field observation, flow of water occures due to the interconnection of fractures. For groundwater modeling in very dense fracture network that presents in the study area, hydraulic conductivity is assigned to every node that is directly proportional to fracture attribute and other rock properties at the corresponding node. It is not suitable to assign unique uniform value of hydraulic conductivity for every lithology. 
Table 2 Result of Calculation of $H C$ values in each Packer and Slug Test Zone

\begin{tabular}{|c|c|c|c|c|c|c|c|c|c|}
\hline Hole ID & Lithology & $\begin{array}{c}\text { K Packer \& } \\
\text { Slug Test }(\mathrm{m} / \mathrm{s})\end{array}$ & $\begin{array}{c}\text { Point } \\
\text { Test }\end{array}$ & $\begin{array}{c}\text { Total } \\
\text { Depth } \\
\text { (m) }\end{array}$ & 1-(RQD/100) & DI & 1-GCD & LPI & HC \\
\hline VZW-094 & Hornblende Trachyandesite & $5.79 \mathrm{E}-06$ & 23.25 & 300 & 0.9 & 0.92 & 0.9 & 0.8 & 0.59778 \\
\hline VZW-094 & Volcanic Breccia & 4.73E-07 & 69.85 & 300 & 0.6 & 0.76 & 0.6 & 0.1 & 0.02762 \\
\hline VZW-094 & Volcanic Breccia & $2.16 \mathrm{E}-07$ & 95.5 & 300 & 0.6 & 0.68 & 0.6 & 0.1 & 0.02454 \\
\hline VZW-094 & Volcanic Breccia & $7.78 \mathrm{E}-08$ & 120.5 & 300 & 0.4 & 0.59 & 0.4 & 0.1 & 0.00957 \\
\hline VZW-094 & Volcanic Breccia & $1.63 \mathrm{E}-07$ & 145.5 & 300 & 0.4 & 0.52 & 0.4 & 0.1 & 0.00824 \\
\hline VZW-094 & Volcanic Breccia & 4.54E-08 & 170.5 & 300 & 0.2 & 0.43 & 0.2 & 0.1 & 0.00173 \\
\hline VZW-094 & Skarn & $1.50 \mathrm{E}-06$ & 196.5 & 300 & 0.8 & 0.34 & 0.8 & 0.8 & 0.17664 \\
\hline VZW-094 & Limestone & $4.27 \mathrm{E}-08$ & 221.5 & 300 & 0.2 & 0.26 & 0.2 & 0.5 & 0.00523 \\
\hline VZW-094 & Limestone & 3.37E-07 & 250 & 300 & 0.5 & 0.16 & 0.5 & 0.5 & 0.02083 \\
\hline VZW-094 & Limestone & $1.51 \mathrm{E}-07$ & 283.5 & 300 & 0.4 & 0.05 & 0.4 & 0.5 & 0.0044 \\
\hline GHD-3885-26 & Volcanic Breccia & $1.08 \mathrm{E}-06$ & 29.95 & 200 & 0.9 & 0.85 & 0.9 & 0.3 & 0.20661 \\
\hline GHD-3885-26 & Volcanic Breccia & $1.43 \mathrm{E}-06$ & 77.75 & 200 & 0.9 & 0.61 & 0.9 & 0.3 & 0.14853 \\
\hline GHD-3885-26 & Volcanic Breccia & $2.06 \mathrm{E}-06$ & 113.2 & 200 & 0.9 & 0.43 & 0.9 & 0.3 & 0.10546 \\
\hline GHD-3885-26 & Hornblende Trachyandesite & 9.64E-07 & 132.2 & 200 & 0.9 & 0.33 & 0.9 & 0.8 & 0.21967 \\
\hline GHD-3885-26 & Hornblende Trachyandesite & 1.79E-06 & 147.75 & 200 & 0.9 & 0.26 & 0.9 & 0.8 & 0.16929 \\
\hline GHD-3885-26 & Hornblende Trachyandesite & $2.11 \mathrm{E}-06$ & 166 & 200 & 0.9 & 0.17 & 0.9 & 0.8 & 0.11016 \\
\hline GHD-3885-26 & Hornblende Trachyandesite & $1.23 \mathrm{E}-06$ & 179.2 & 200 & 0.9 & 0.10 & 0.9 & 0.8 & 0.06739 \\
\hline GHD-3885-26 & Hornblende Trachyandesite & 9.97E-07 & 192.5 & 200 & 0.9 & 0.03 & 0.9 & 0.8 & 0.0243 \\
\hline CSTG-01 & Alluvium & $3.98 \mathrm{E}-07$ & 17.05 & 137.5 & 0.6 & 0.87 & 0.6 & 0.8 & 0.25229 \\
\hline CSTG-02B & Alluvium & $1.75 \mathrm{E}-06$ & 29.71 & 108.5 & 0.9 & 0.72 & 0.9 & 0.8 & 0.47056 \\
\hline VZW-17S & Alluvium & $1.52 \mathrm{E}-06$ & 23.76 & 121.7 & 0.9 & 0.80 & 0.9 & 0.8 & 0.52149 \\
\hline OHS-21 & Overburden & 8.79E-07 & 12.36 & 205.1 & 1 & 0.93 & 1 & 1 & 0.93974 \\
\hline VZW-25A & Overburden & $2.71 \mathrm{E}-06$ & 3.12 & 74 & 1 & 0.95 & 1 & 1 & 0.95784 \\
\hline VZW-31 & Quartz Monzonite & $9.57 \mathrm{E}-07$ & 118.59 & 347.9 & 0.5 & 0.65 & 0.5 & 0.2 & 0.03296 \\
\hline VZW-58 & Quartz Monzonite & $1.38 \mathrm{E}-06$ & 329.09 & 700 & 1 & 0.52 & 1 & 0.7 & 0.37091 \\
\hline VZW-74 & Quartz Monzonite & $3.97 \mathrm{E}-08$ & 28.5 & 500 & 0.2 & 0.94 & 0.2 & 0.2 & 0.00754 \\
\hline VZW-50 & Quartz Monzodiorite & $3.76 \mathrm{E}-07$ & 277 & 399.6 & 0.4 & 0.30 & 0.4 & 0.1 & 0.00491 \\
\hline VZW-55 & Quartz Monzodiorite & $2.55 \mathrm{E}-07$ & 28.51 & 132.8 & 0.4 & 0.78 & 0.4 & 0.1 & 0.01257 \\
\hline VZW-62 & Quartz Monzodiorite & $1.74 \mathrm{E}-08$ & 87.14 & 200.2 & 0.5 & 0.56 & 0.5 & 0.1 & 0.01412 \\
\hline VZW-17 & Granodiorite & $1.17 \mathrm{E}-07$ & 280.5 & 432.5 & 0.1 & 0.35 & 0.1 & 0.1 & 0.00035 \\
\hline VZW-76 & Trachyandesite & 4.13E-08 & 94.18 & 300 & 0.1 & 0.68 & 0.1 & 0.1 & 0.00069 \\
\hline VZW-51 & Volcanic Breccia & $7.36 \mathrm{E}-07$ & 18.7 & 101.5 & 0.8 & 0.81 & 0.8 & 0.3 & 0.15663 \\
\hline VZW-29 & Limestone & 7.53E-09 & 305.85 & 408.61 & 0.1 & 0.25 & 0.1 & 0.1 & 0.00025 \\
\hline VZW-29S & Limestone & $5.46 \mathrm{E}-08$ & 6.46 & 27.5 & 0.2 & 0.76 & 0.2 & 0.1 & 0.00306 \\
\hline VZW-40 & Limestone & $1.59 \mathrm{E}-06$ & 11.73 & 400 & 0.9 & 0.97 & 0.9 & 1 & 0.78625 \\
\hline VZW-49D & Limestone & $7.52 \mathrm{E}-07$ & 14.6 & 550 & 0.6 & 0.97 & 0.6 & 0.5 & 0.17522 \\
\hline VZW-52 & Limestone & $1.09 \mathrm{E}-06$ & 11.4 & 267.45 & 0.9 & 0.95 & 0.9 & 1 & 0.77547 \\
\hline VZW-53A & Limestone & $2.82 \mathrm{E}-06$ & 27.5 & 489.8 & 0.9 & 0.94 & 0.9 & 1 & 0.76452 \\
\hline VZW-59 & Limestone & $7.05 \mathrm{E}-07$ & 227.02 & 401 & 0.6 & 0.43 & 0.6 & 0.5 & 0.0781 \\
\hline VZW-63 & Limestone & $3.38 \mathrm{E}-06$ & 46.97 & 500 & 1 & 0.90 & 1 & 1 & 0.90606 \\
\hline VZW-68 & Limestone & $2.27 \mathrm{E}-06$ & 288.2 & 400 & 1 & 0.27 & 1 & 1 & 0.2795 \\
\hline VZW-69 & Limestone & $1.21 \mathrm{E}-06$ & 210.42 & 400 & 1 & 0.47 & 1 & 1 & 0.47395 \\
\hline VZW-71 & Sandstone & $2.06 \mathrm{E}-07$ & 307.58 & 351 & 0.3 & 0.12 & 0.3 & 0.9 & 0.01002 \\
\hline VZW-75 & Limestone & $3.01 \mathrm{E}-07$ & 164.61 & 350 & 0.5 & 0.52 & 0.5 & 0.5 & 0.06621 \\
\hline VZW-39 & Limestone & $2.04 \mathrm{E}-08$ & 152.62 & 300.8 & 0.2 & 0.49 & 0.2 & 0.1 & 0.00197 \\
\hline VZW-61 & Limestone & $7.36 \mathrm{E}-08$ & 87.8 & 375.2 & 0.2 & 0.76 & 0.2 & 0.1 & 0.00306 \\
\hline VZW-73 & Limestone & 5.29E-08 & 71.65 & 450 & 0.2 & 0.84 & 0.2 & 0.1 & 0.00336 \\
\hline VZW-245 & Volcanic Breccia & $1.14 \mathrm{E}-08$ & 94.91 & 120 & 0.5 & 0.20 & 0.5 & 0.1 & 0.00523 \\
\hline VZW-244 & Limestone & $1.46 \mathrm{E}-07$ & 66.37 & 150 & 0.5 & 0.55 & 0.5 & 0.1 & 0.01394 \\
\hline
\end{tabular}

\section{HC-System Model}

Hydraulic conductivity from 49 pairs of packer and slug test results as well as form $\mathrm{HC}$ value at the same zones were analyzed by means of trend line using power law option. Regression analysis was conducted to find out the correlation between the hydraulic conductivity from $\mathrm{HC}$ value (Table 2) against the value from packer and slug test results. The result from relationship of $\mathrm{HC}$ Index and field observation are depicted in Figure 1.a. Hydraulic conductivity distribution of the study site can be expressed empirically as follows.

$$
\mathrm{K}=2 \times 10^{-6} \times \mathrm{HC}^{0,5571}
$$

Equation 5, is built from 40 observation data, among them 9 data are used for validation test. From Figure 1.a, relationship of $\mathrm{HC}$ Index and Observation give coefficient determination of $\mathrm{R}^{2}=0,71$. Following Iskandar et al (2014), any influences from Depth Index may possibly present on equation. In Hsu et al (2009) the drilling is fully vertical. On the other hand, the drilling in this study are performed in various direction. From Figure 1.b Relationship between 9 data from observation against the value resulting equation 5 leads to a coefficient determination $\mathrm{R}^{2}=0,86$. The results of $3 \mathrm{D}$ distribution of hydraulic conductivity following HC-system for 4896 geotechnical node can be seen on Figure 2. 


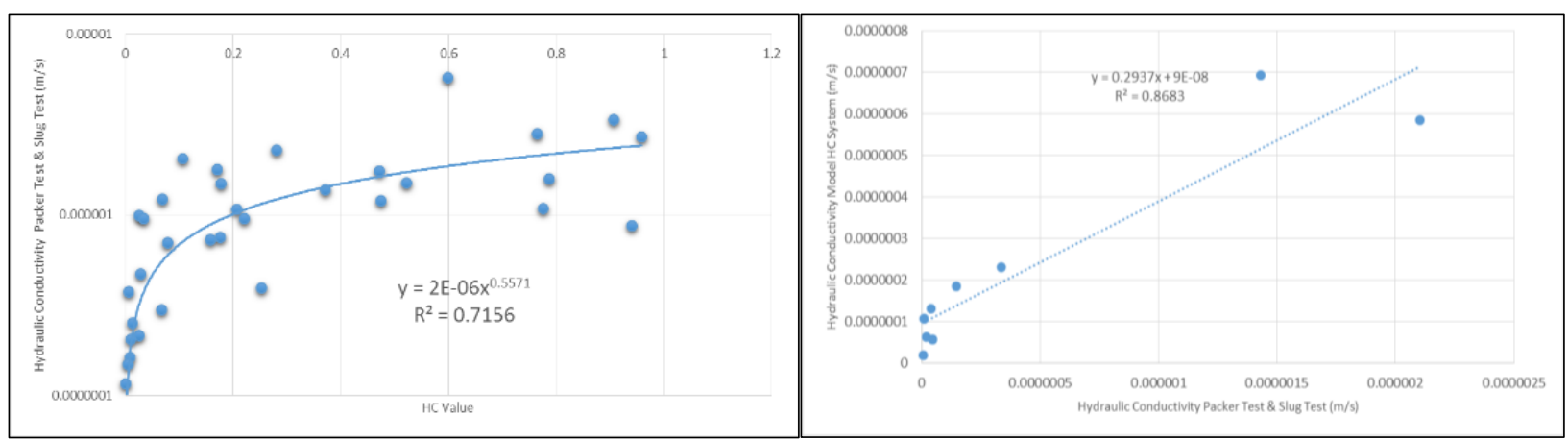

Fig. 1 a. Correlation between HC-Index and Hydraulic Conductivity from Packer and Slug Test (Left) b. Validation using 9 Data from Observation against HC-System (Right)

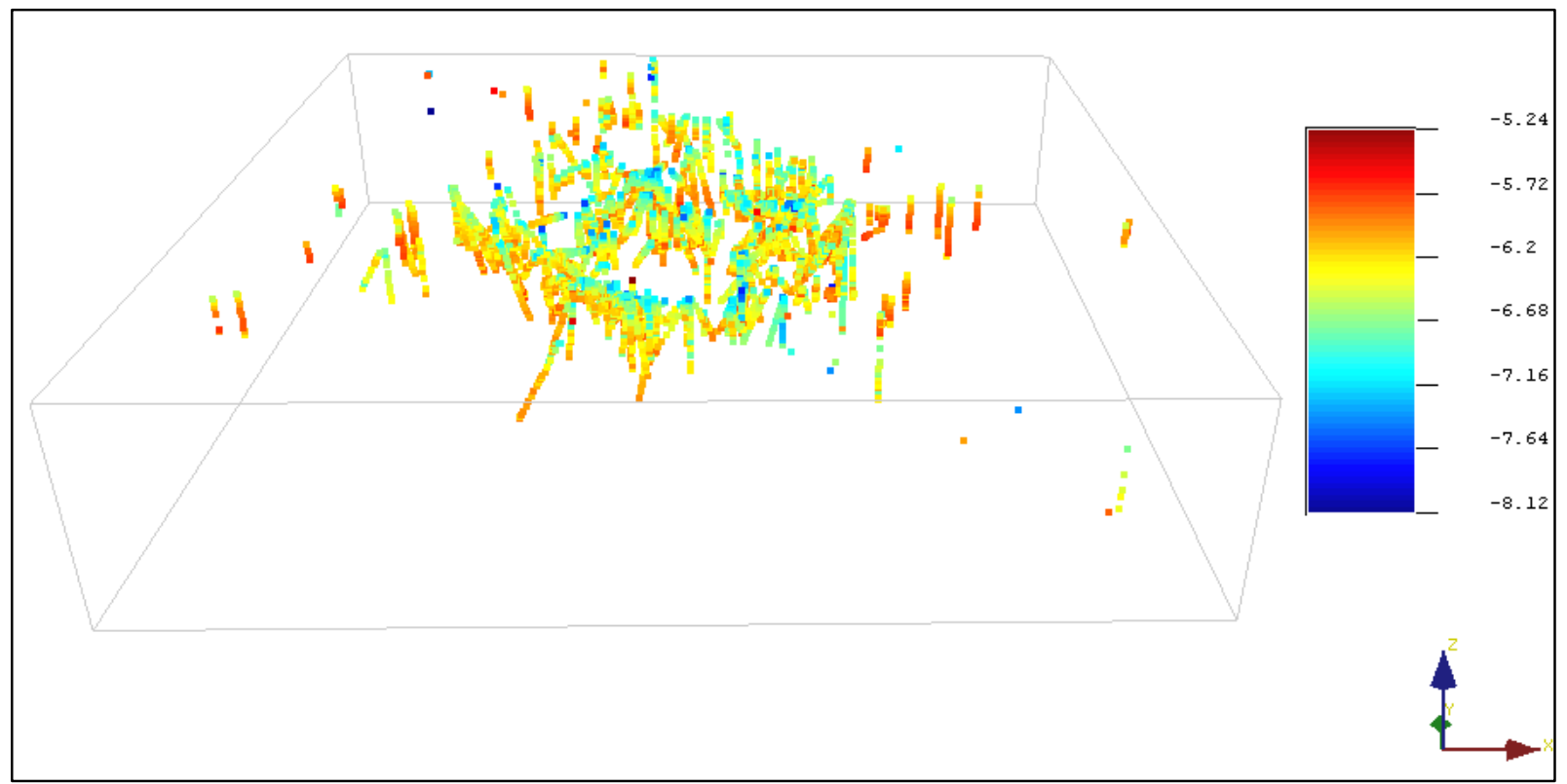

Fig. 2 Hydraulic Conductivity Distribution in Bore Holes according to HC-System

\section{Artificial Neural Network Model}

Results of 3D hydraulic conductivity distribution from HC-system is used to input into ANN. Mabruri et al (2015) performed segmented training that that creates several ANN network for lesser range of data, which means reducing complexity of data to be trained by ANN and only applied to small limited range of input data. In this study, original data is sorted by depth (Z) then customized ANN is trained for first 5 upper data to model $\log \mathrm{K}$ distribution from depth surface until the $5^{\text {th }}$ data depth, Furthermore, a new customized ANN is trained for data number 2-6. This applies, continuously until last the step of last customized ANN that trains the data number 4891-4896. Z (depth) segmented training is selected because in every $\mathrm{Z}$ segment, the data is distributed normally in XY plane. Total customized ANN will be 4891 networks function that can be used to model $\log \mathrm{K}$ distribution for each range custom ANN input. After training, predicting of $\mathrm{K}$ distribution will be continuously made on $\mathrm{X}, \mathrm{Y}$ plane. Best performance with MSE $<10^{-10}$ is used to control quality of training. Each trained segment is used to predict log K spatial distribution in its segment range, and every segment of spatial distribution data is combined and gives the final model result as shown in Figure 3.a. According to the geology condition, Grasberg pit consists of igneous rock from intrusion and it can be seen at the center of picture. Hydraulic conductivity of intrusion ranges between log $\mathrm{K}-9$ to $-7 \mathrm{~m} / \mathrm{s}$ (blue color). At surrounding pit, outside of alteration zone, the hydraulic conductivity falls within $\log \mathrm{K}-4$ to $-6 \mathrm{~m} / \mathrm{s}$ (yellow color). It is due to the sedimentary rocks surrounding the pit that consists of mainly limestone with karstic features. It is apparent that heterogenous hydraulic conductivity distribution is controlled by geological complex and structure. Figure 3.b shows the coefficient determination $\mathrm{R}^{2}=0,6$. This condition is affected by grid system. The grid with dimension of $50 \times 50 \times 15$ meter is considered a large grid. More accurate distribution needs smaller grid. 


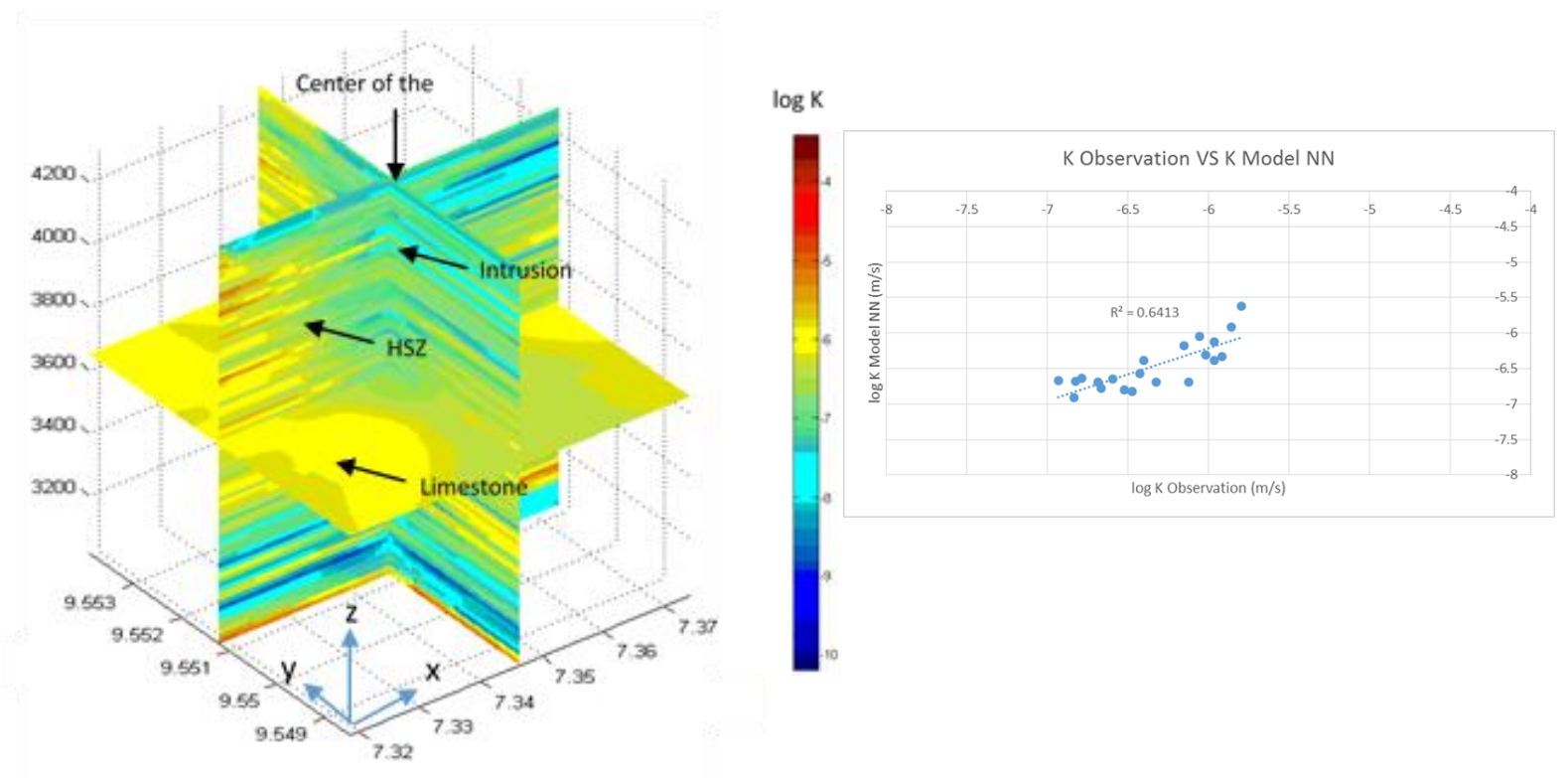

Fig. 3 a. Hydraulic conductivity distribution on Grasberg (Left)

b. Validation of ANN Modeled Hydraulic Conductivity against Observational Data (Right)

\section{CONCLUSION}

Based on this study, it can be concluded as follows:

1. Grasberg zone is controlled by complex geology and structure that results in secondary aquifer and heterogeneous characteristic such hydraulic conductivity.

2. Hydraulic conductivity values from HC-System approach at the study area varies in the range from $10^{-5}$ to $10^{-8} \mathrm{~m} / \mathrm{s}$.

3. Hydraulic conductivity distribution model according to ANN ranges from $10^{-3.5}$ to $10^{-10} \mathrm{~m} / \mathrm{s}$.

4. ANN with segemented method gives good interpretation of 3D distribution hydraulic conductivity model.

\section{ACKNOWLEDGMENT}

The authors gratefully acknowledge the PTFI for giving permit to use the data. Secondly, thank to Prof. Dr. Sudarto Notosiswoyo and Dr. Zuheir Syihab, Hafidz Mabruri and Mining Hydrogeology Laboratory ITB for the developement the program and their support on writing this paper.

\section{REFERENCES}

Deere, D. U., Hendron, A. J., Patton, F. D., Cording, E. J., Design of Surface and Near Surface Construction In Rock, Proceedings of 8th U.S. Symposium. Rock Mechanics, AIME, pp. 237-302, New York (1967).

Grasberg Geoservice at Geotech, Hydrology, and Geology Division PTFI, Geology Structure and Hydrology Measurement. Internal Report, not published (2014).

HCI, Conceptual Hydrogeological Model and GroundWater Flow Modeling of Grasberg Mine and Surrounding Area, Internal Report, PTFI, Indonesia
(2003).

Hsu S.M., Lo H.C., Chi S.Y., Ku C.Y., An empirical model for estimating hydraulic conductivity of highly disturbed clastic sedimentary rocks in Taiwan, Engineering Geology 109, p. 213-223 (2009).

Iskandar I., Wibowo A., Casanova B., Notosiswoyo S., A 3D Model of Hydraulic Conductivity Distribution of Fractured Rocks Using Packer Test Result and Geotechnical Log, International Symposium on Earth Science and Technology, University of Kyushu, Japan (2014).

Lee C.H., Farmer I., Fluid Flow in Discontinuous Rocks, Chapman \& Hall, London, UK (1993).

Mabruri H.,, Cahyadi T.A., Widodo L.E., Iskandar I., Modeling of 3D Isotropic Distribution of Hydraulic Conductivity using Neural Network, ICAST, Institute of Technology Surabaya, Indonesia (2015).

Schaap, M.G., Bouten, W., Modeling Water Retention Curves of SSandy Soils using Neural Networks. Water Resour. Res. 32 (10), 3033-3040 (1996).

Silaen H., Pramuji, Ginting A., Widyanto D., Waromi I., Hydrogeological and Pore Water Pressure Characterization At South West Sector of Grasberg Open Pit, Papua, Proceedings JCM Makassar The $36 \mathrm{t}^{\mathrm{h}}$ HAGI and $40^{\text {th }}$ IAGI Annual Convention and Exhibition (2011). 